\title{
Influence of coarse aggregate on shear resistance of self-consolidating concrete beams
}

\author{
Influência do agregado graúdo na resistência ao \\ cisalhamento de vigas de concreto autoadensável
}

G. SAVARIS a

gsavaris@utfpr.edu.br

R. C. A. PINTO r.pinto@ufsc.br

\begin{abstract}
Self-compacting concrete can be characterized by its flowability, achieved by adding superplasticizer and reducing the amount and particle size of coarse aggregate in relation to conventional concrete, which allows passing by the reinforcement and filling the forms without the need for mechanical vibration. The reduction in volume and particle size of the coarse aggregate can result in lower shear strength of beams due to reduced aggregate interlock. Therefore, an experimental investigation was conducted objecting to evaluate the influence of the reduction in volume content and the nominal size of coarse aggregate on the concrete shear strength. Six concrete mixes, four self-compacting and two conventionally vibrated, were used for a total of 18 beams with longitudinal reinforcement and without shear reinforcement. These beams were tested under four-point loading condition. Their failure modes, cracking patterns and shear resistance were evaluated. The shear resistances were compared to the theoretical values given by the ACl-318 and EC-2 codes. The results demonstrated a lower shear resistance of self-compacting concrete beams, caused mainly due to the reduced aggregate size.
\end{abstract}

Keywords: self-consolidating concrete, shear resistance, aggregate interlock, beams.

\section{Resumo}

O concreto autoadensável pode ser caracterizado pela sua fluidez, obtida a partir da utilização de aditivos superplastificantes e da redução da granulometria e volume de agregado graúdo em relação ao concreto convencional, o que possibilita a transposição das armaduras e o preenchimento das formas sem a necessidade de vibração mecânica. Esta redução do volume e da granulometria do agregado graúdo pode acarretar em uma menor resistência ao cisalhamento de vigas devido à uma possível redução do efeito de engrenamento entre os agregados. Sendo assim, um programa experimental foi realizado com a intenção de investigar a influência da redução do volume e do diâmetro máximo do agregado graúdo na resistência ao cisalhamento. Foram utilizadas seis dosagens, quatro de concreto autoadensável e duas de concreto convencionalmente vibrado para um total de 18 vigas com armadura de flexão e sem armadura transversal. Estas vigas foram ensaiadas à flexão a quatro pontos sendo avaliados os modos de ruptura, padrões de fissuração e a força cortante última. As resistências obtidas experimentalmente foram comparadas com as estimativas das normas ACl-318 e EC-2. Os resultados demonstram menor resistência ao cisalhamento em vigas de concreto autoadensável em relação ao concreto convencional, principalmente quando reduzido o diâmetro máximo do agregado.

Palavras-chave: concreto autoadensável, resistência ao cisalhamento, engrenamento de agregados, vigas. 


\section{Introduction}

Recent researches have enabled the development of new materials and improvements in properties of usually employed materials, in order to optimize the construction process. In the late 80 , the reduction of skilled workers and the need to increase the durability of reinforced concrete structures led researchers at the University of Tokyo to develop a high-performance concrete, characterized by the ability to flow under its own weight. This new material, named self-consolidating concrete, was able to fill the formwork and to pass through reinforcing bars without the need of vibration [1]. The higher flowability of self-consolidating concrete (CA), as compared to conventional vibrated concrete (CC), is obtained by limiting the volume and the size of the coarse aggregates, by adding superplasticizer (SP) and a viscosity-modifying admixture (VMA) in some cases to improve concrete behavior and to avoid segregation. Also, in order to increase water retention and viscosity of the mixture, fine materials are employed, such as limestone filler, fly ash, silica fume and metakaolin. However, the proportion of these fine constituents depends on the characteristics of materials, the mixing equipment, and the use of concrete [2].

According to EFNARC [3], self-consolidating concrete has the same engineering properties of traditional vibrated concrete. It may have a higher compressive strength due to a better compaction. Parra et al. [4] reported that besides the more efficient compaction, the use of superplasticizers and the reduction of the water/ cement (w/c) ratio led to higher compression strength of concrete. Recent researches with conventional concretes have shown that the nominal size of the coarse aggregate directly influences the aggregate interlock through the shear crack surfaces. Higher shear resistance was obtained with concrete mixtures with larger aggregates [5] [6]. Since self-consolidating concrete requires lesser amount and smaller size of coarse aggregate, a reduction in its shear strength as compared to conventional concrete's could be expected [7].

However, there is no agreement among researchers of this reduction in shear strength with self-consolidating concrete. Desnerck et al. [8] suggest that improvements in the concrete matrix provided by a higher amount of fine materials may result in an increased friction between the surfaces of the cracks. This increased friction

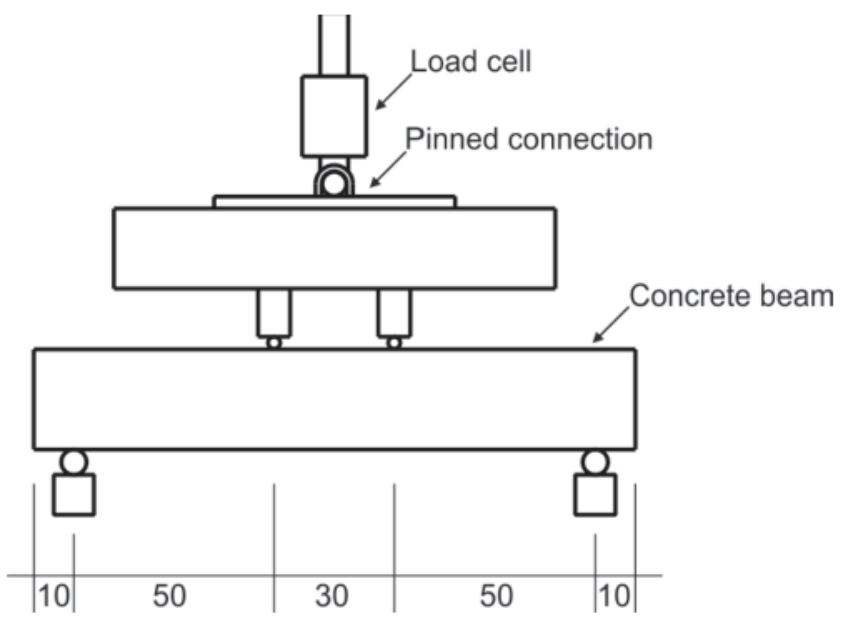

Figure 1

Four-point bending test set-up (dimensions in cm)

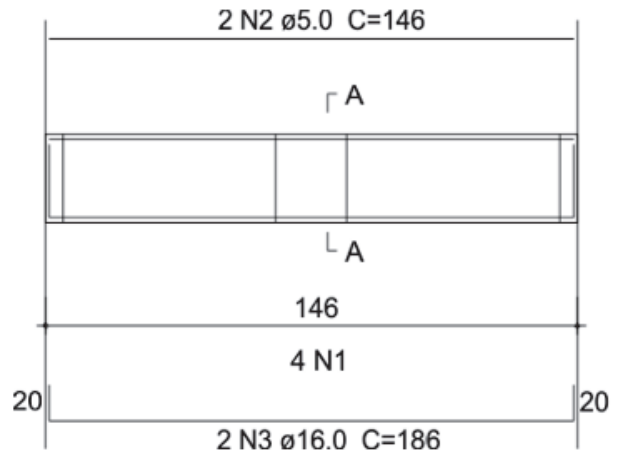

SEÇÃO A-A

Figure 2

Beam dimension and reinforcement

would supply the reduction of the aggregate interlock and could even increase shear strength.

Although self-consolidating concrete exists for almost three decades, there are divergences among researchers regarding the behavior and design of reinforced concrete structures with this material. Therefore, it is necessary to evaluate the influence of using smaller coarse aggregate size with reduced volume fraction on the shear strength of self-consolidating concrete beams. Current shear design methods also need to be evaluated.

This paper presents the results of an experimental investigation on the behavior of conventional and self-consolidating concrete beams with flexural reinforcement only. Eighteen concrete beams were produced using six different concrete mixes. Two conventional mixtures were produced with two different sizes of coarse aggregate, 9.5 and 19 $\mathrm{mm}$. Two other self-consolidating mixtures were also produced with these aggregate sizes. The last two mixtures were self-consolidating mixtures in which the volume of coarse aggregates was reduced by $30 \%$. The beams were subjected to four-point bending test. Their failure mode, cracking patterns and ultimate shear strength were measured. The experimental tests results were compared to the equations given by $\mathrm{ACl} 318$ [9] and EC-2 [10].

\section{Experimental program}

\subsection{Beam specimens}

The beams were designed with adequate flexural reinforcement and no shear reinforcement, so that failure would occur by diagonal tension. All beams were $10 \mathrm{~cm}$ wide $\left(b_{w}\right), 25 \mathrm{~cm}$ depth $(\mathrm{h})$ with a total length of $150 \mathrm{~cm}$, providing an effective span of $130 \mathrm{~cm}$. The specimens were tested as simply supported under four-point loading condition, with loading distant $50 \mathrm{~cm}$ from the support, resulting in a shear span-to-depth ratio (a/d) close to 2.25. Figure 1 schematically presents the experimental set-up.

All beams had a flexural reinforcement of one layer with two 500 $\mathrm{MPa}$ yield strength $16 \mathrm{~mm}$ reinforcing bars, which, correspond to a flexural reinforcement ratio of $1.61 \%$. Two other reinforcing bars were positioned at the upper part of the cross section, and four others as stirrups placed at the ends and in the central region of the beam. These reinforcing bars were of $5 \mathrm{~mm}$ diameter with yield strength of $600 \mathrm{MPa}$, as shown in Figure 2. 
Table 1

Mixture proportions for CC and CA mixtures $\left(\mathrm{kg} / \mathrm{m}^{3}\right)$

\begin{tabular}{|c|c|c|c|c|c|c|c|c|}
\hline Concrete & $\begin{array}{l}\text { Cement } \\
(\mathrm{kg})\end{array}$ & $\begin{array}{l}\text { Filler } \\
(\mathrm{kg})\end{array}$ & $\begin{array}{l}\text { Natural } \\
\text { sand } \\
(\mathrm{kg})\end{array}$ & $\begin{array}{l}\text { Artificial } \\
\text { sand } \\
(\mathrm{kg})\end{array}$ & $\begin{array}{c}\text { Coarse } \\
\text { aggregate } \\
0 \\
(\mathrm{~kg})\end{array}$ & $\begin{array}{c}\text { Coarse } \\
\text { aggregate } \\
1 \\
(\mathrm{~kg})\end{array}$ & $\begin{array}{l}\text { Water } \\
(\mathrm{kg})\end{array}$ & $\begin{array}{l}\text { Superplasticizer } \\
(\mathrm{kg})\end{array}$ \\
\hline $\mathrm{CCl}$ & 385.18 & - & 418.54 & 417.41 & - & 964.59 & 200.29 & - \\
\hline $\mathrm{CCO}$ & 385.18 & - & 418.54 & 417.41 & 961.10 & - & 200.29 & - \\
\hline CAIN & 385.18 & 214.77 & 312.88 & 312.04 & - & 964.59 & 200.29 & 0.87 \\
\hline CAON & 385.18 & 214.77 & 312.88 & 312.04 & 961.10 & - & 200.29 & 0.77 \\
\hline CA1R & 385.72 & 215.08 & 456.45 & 455.23 & - & 676.02 & 200.57 & 1.15 \\
\hline CAOR & 385.72 & 215.08 & 456.45 & 455.23 & 673.58 & - & 200.57 & 1.11 \\
\hline
\end{tabular}

\subsection{Mix design}

In order to evaluate three factors that, according to the literature, differentiate self-consolidating concrete from conventional concrete: flowability, nominal size of coarse aggregate and coarse aggregate volume fraction in the mix, five concrete mixtures were established from a conventional concrete mixture. The mix design has a target strength close to $40 \mathrm{MPa}$.

The mixes were designated by the type of concrete, conventional (CC) or self-consolidating (CA), the maximum aggregate size, 9.5 $\mathrm{mm}(0)$ or $19.0 \mathrm{~mm}(1)$, and the volume of coarse aggregate normal, $(\mathrm{N})$ or reduced by $30 \%(\mathrm{R})$. This $30 \%$ reduction in the mix design was compensated with an increase in the fine aggregate content. All self-consolidating concrete mixes were produced with limestone filler and a polycarboxylate-based superplasticizer, in order to promote high-viscosity and high flowability.

Brazilian Portland cement type CP V-ARI-RS with high initial strength and sulfate resistance was used, enabling formwork removal after 24 hours of casting. This type of cement is frequently used in the production of self-consolidating concrete. A composition of $50 \%$ natural fine quartz sand and $50 \%$ artificial crushed granite rock sand was used as fine aggregate. The coarse aggregates were crushed granite rock with maximum nominal sizes of $9.5 \mathrm{~mm}$ and $19.0 \mathrm{~mm}$. Conventional concretes were produced without the use of additives. Table 1 presents the concrete mix proportions.
All mixes had the same 0.52 water/cement ratio. The superplasticizer amount was adjusted according to the slump flow reached for each self-consolidating mix, resulting in amounts between $0.2 \%$ and $0.3 \%$ of the cement mass.

Self-consolidating concrete mix with normal coarse aggregate volume fraction underwent a $25 \%$ replacement of dry fine aggregate mass by limestone filler. The same amount of filler was used in the concrete with reduced coarse aggregate volume fraction, thus keeping the amount of fine materials in concrete around $600 \mathrm{~kg} /$ $\mathrm{m}^{3}$ to all self-consolidating concretes. CAON, CA1N, CC0 and CC1 mortar content was $56 \%$ while mortar content of CA1R and CAOR rose to $69 \%$ due to the reduced volume of coarse aggregate and consequently increase volume of fine aggregates.

Slump test was performed for conventional concrete to evaluate its workability according to Brazilian standard NBR NM 67 [11]. The fresh properties of self-consolidating concrete such as flowability, passing ability and plastic viscosity were determined by Brazilian standard NBR 15823 [12]. The compressive strengths of all mixtures were determined in compliance with NBR 5739 [13] standard on cylinders specimens. The results are summarized in Table 2.

\subsection{Casting and instrumentation}

A 150 liter concrete mixer was used to produce all concrete mixtures. Three beams and three cylindrical specimens per

\section{Table 2}

Fresh and hardened properties of CC and CA mixtures

\begin{tabular}{|c|c|c|c|c|c|c|}
\hline Concrete & $\begin{array}{c}\text { Slump } \\
(\mathbf{m m})\end{array}$ & $\begin{array}{c}\text { Slump flow } \\
(\mathbf{m m})\end{array}$ & $\begin{array}{c}\text { Density } \\
\left(\mathbf{k g} / \mathbf{m}^{3}\right)\end{array}$ & $\begin{array}{c}\text { V-funnel } \\
(\mathbf{s})\end{array}$ & $\begin{array}{c}\text { L-box } \\
(\mathbf{m m})\end{array}$ & $\begin{array}{c}\text { Natural sand } \\
(\mathbf{k g})\end{array}$ \\
\hline CC1 & 385.18 & - & 418.54 & 417.41 & 418.54 & 418.54 \\
\hline CCO & 385.18 & - & 418.54 & 417.41 & 418.54 & 418.54 \\
\hline CA1N & 385.18 & 214.77 & 312.88 & 312.04 & 312.88 & 312.88 \\
\hline CAON & 385.18 & 214.77 & 312.88 & 312.04 & 312.88 & 312.88 \\
\hline CA1R & 385.72 & 215.08 & 456.45 & 455.23 & 456.45 & 456.45 \\
\hline CAOR & 385.72 & 215.08 & 456.45 & 455.23 & 456.45 & 456.45 \\
\hline
\end{tabular}




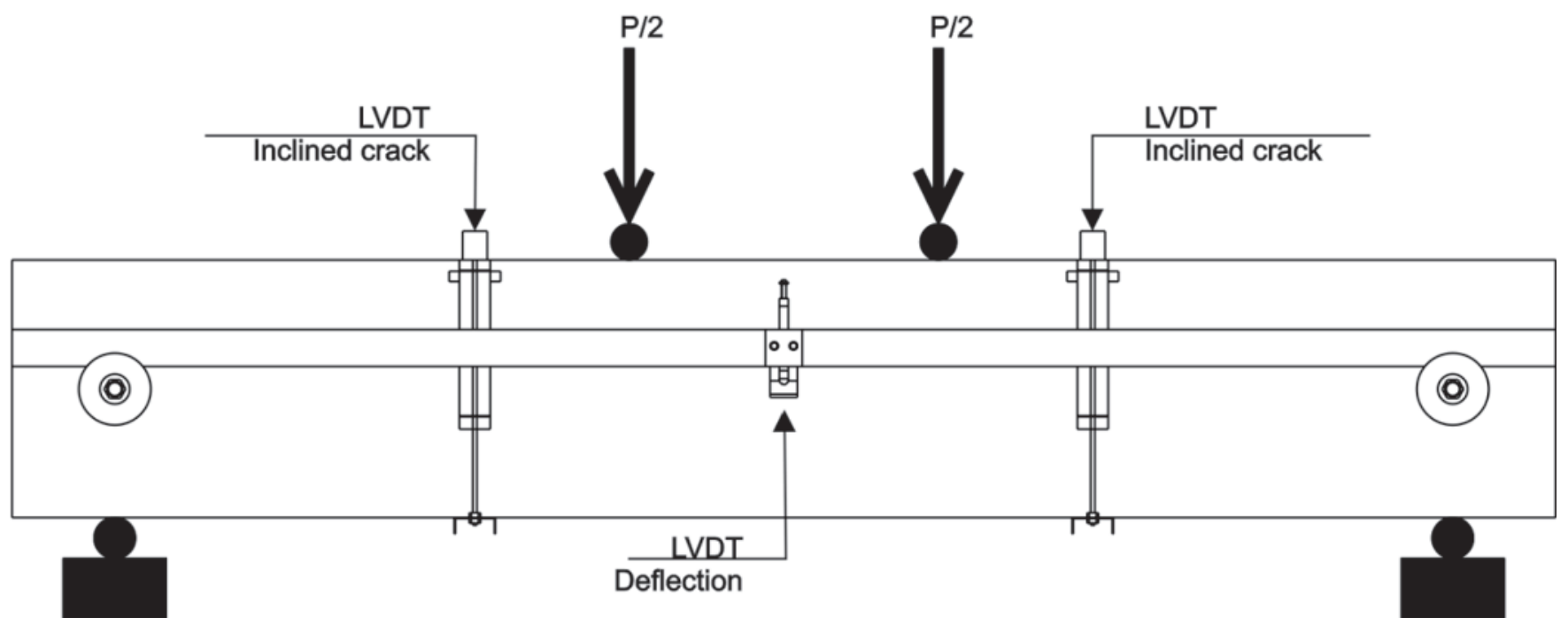

Figure 3

Beam instrumentation

batch were cast. The formworks were made of medium density fiberboard (MDF). A $25 \mathrm{~mm}$ needle immersion vibrator was applied to consolidate the conventional concrete beams.

The formworks were removed after 24 hours of casting. The beams and the cylinder specimens were then stored under a plastic tarpaulin bag, moistened daily for the first seven days. All beams and specimens remained in laboratory conditions, with an average temperature of $22.5^{\circ} \mathrm{C}$ and relative humidity about $75.4 \%$. The tests were performed after 28 days.

Beam instrumentation is schematically shown in Figure 3. In order to measure the central deflection, two linear variable displacement transducers (LVDTs), with $10 \mathrm{~mm}$ measurement capability, were placed on each side of the beam. The LVDTs were fixed in aluminum bars supported by sheaves screwed on the ends of the beams. In the mid-span of the beam, steel angles bolted close to the expected neutral axis served as support bases for the LVDTs measures.

The width of the inclined shear cracks were measured by LVDTs installed $15 \mathrm{~cm}$ distant from the load application points. They were fixed with screws on the top side face of the beam and on a steel angle screwed into the lower face of the beam. Since the initial crack could appear on both sides of the beam, two LVDTs were used.

The load was applied using a hydraulic jack coupled to a $200 \mathrm{kN}$ load cell capacity at a load increase ratio of $500 \mathrm{~N} / \mathrm{s}$ until shear failure. Loading stopped at $20 \mathrm{kN}$ and $40 \mathrm{kN}$, to allow to evaluate the number and extension of the cracks.

The displacement transducers and load cell were connected to a data acquisition system, which allowed acquiring information about deflection and shear crack opening during loading.

\section{Test results and discussion}

\subsection{Cracking pattern and failure}

Figures 4 to 6 present the observed cracking patterns of the con- ventional and the self-consolidating concrete beams after failure. The numbers indicate the cracks observed at the applied load in $\mathrm{kN}$, whereas the letter " $\mathrm{R}$ " represents the cracks that occurred between the last stop and failure. The vertical dotted lines correspond to the LVDT position measuring the inclined crack width, while the inclined dashed lines correspond to the angle of shear crack with the corresponding value indicated at the top of the beam face.

Initially, flexural cracks developed in the mid-span of the beam, propagating vertically with increased loading followed by some inclined cracks with small slope in the shear regions.

At the final load stages, a sudden formation of the shear crack occurred in one or both shear spans. This crack propagated rapidly diagonally towards the load application point and the support. Simultaneously, parallel cracks to the flexural reinforcement bars developed, since the bond stress between reinforcing bars and concrete was surpassed. A sudden failure of the beam followed.

The development of the shear crack could be observed visually during loading, being confirmed by a sudden jump in the elongation of the LVDTs mounted for measuring deflections and for the shear crack widths. However, due to the lack of shear reinforcement, the failure occurred shortly after this crack formation.

The inclination of the shear cracks was determined considering a tangent line to crack at the mid depth of the beam, intercepting the points where there was a sudden change in slope. It was noted that the angle varied between $27.2^{\circ}$ and $42.6^{\circ}$, with an average angle greater for conventional concrete than for self-consolidating concrete.

\subsection{Shear resistance}

According to some code based equations, shear resistance of reinforced concrete beams is related to the concrete compressive strength. The American Building Code ACl 318 [9] considers that the ultimate shear force of beams is proportional to the square root of this strength while the European Standard EC-2 [10] considers it proportional to the cube root. 

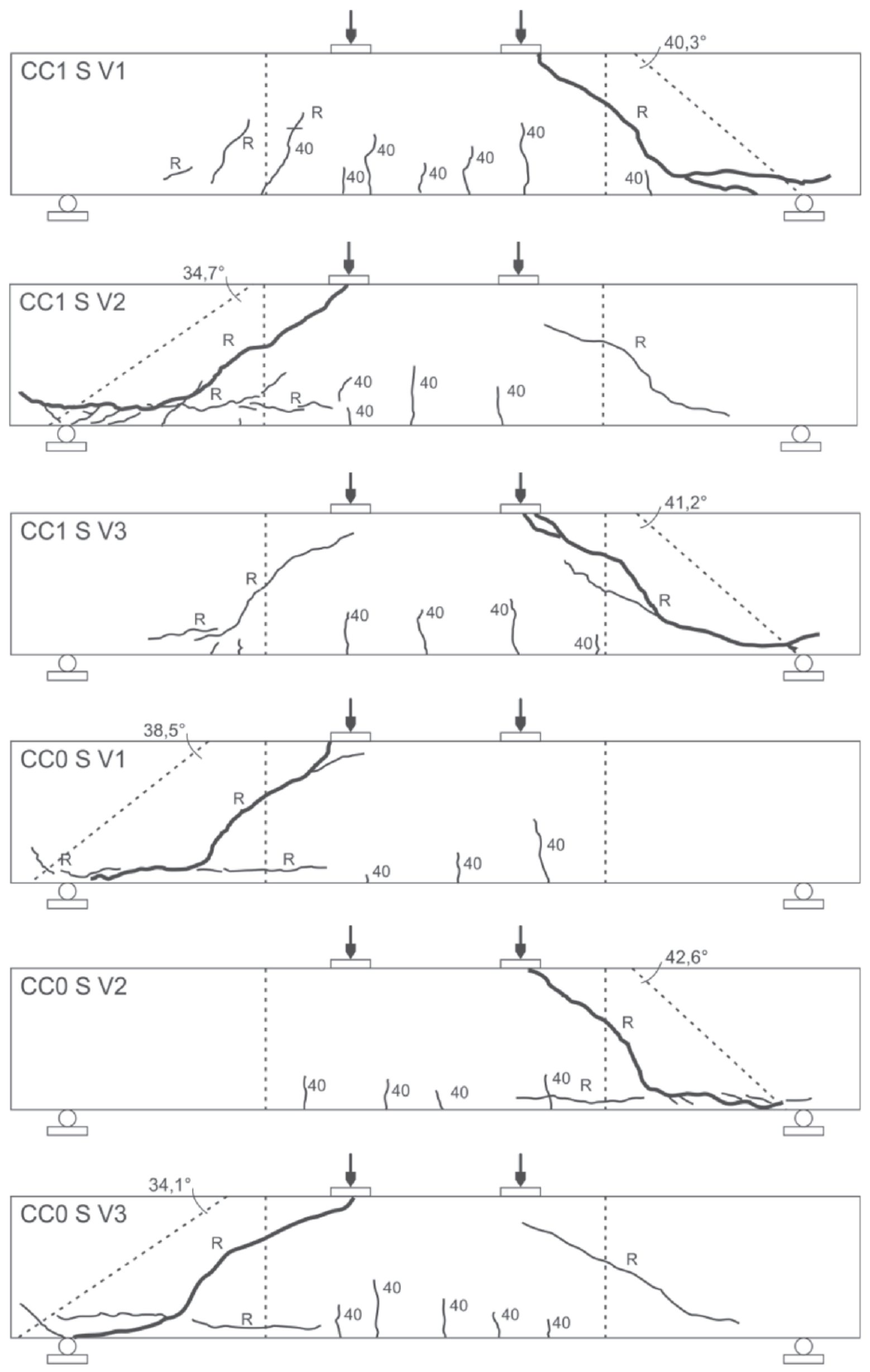

Figure 4

Crack patterns of conventional concrete beams 

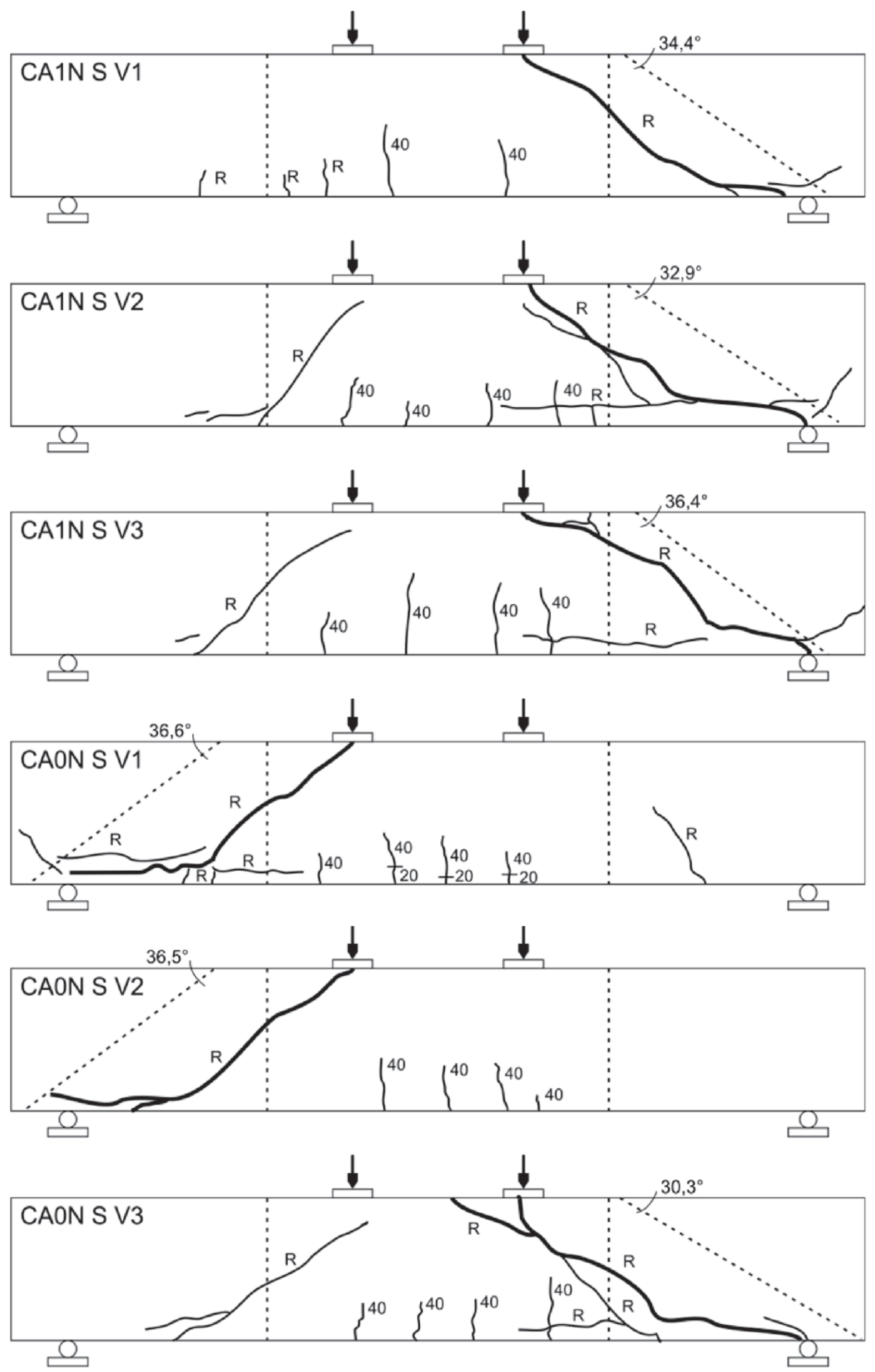

Figure 5

Crack patterns of self-consolidating concrete beams with normal amount of coarse aggregate 

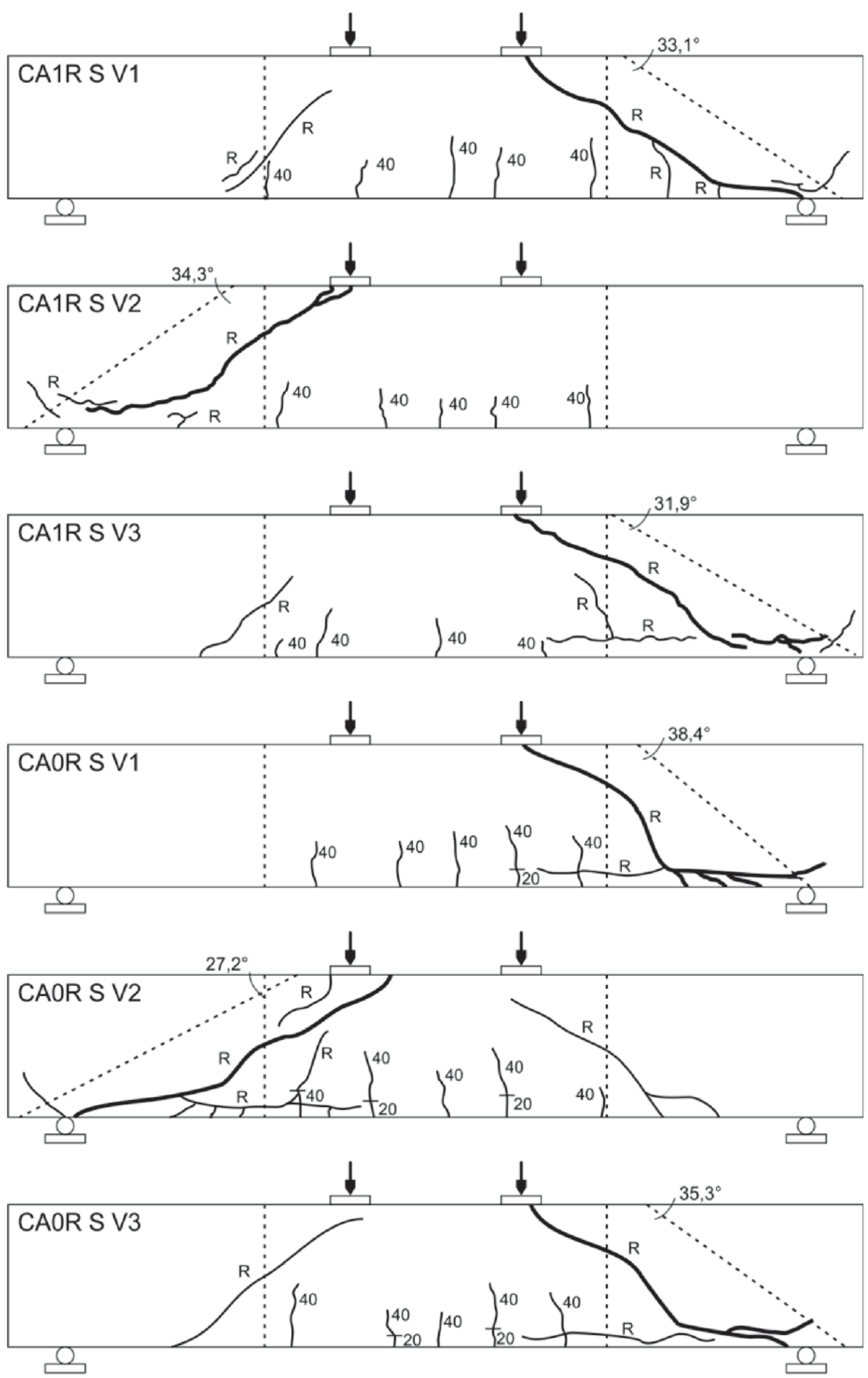

Figure 6

Crack patterns of self-consolidating concrete beams with reduced amount of coarse aggregate 
Table 3

Ultimate shear capacity, normalized and average value, and shear crack inclination angle

\begin{tabular}{|c|c|c|c|c|c|}
\hline Concrete & $\begin{array}{c}V_{u} \\
(k N)\end{array}$ & $\begin{array}{c}\mathrm{V}_{\mathrm{n}} \\
(\mathrm{kN} \cdot \mathrm{MPa}-0,5)\end{array}$ & $\begin{array}{c}V_{n, m} \\
(k N . M P a-0,5)\end{array}$ & $\begin{array}{c}\text { Crack angle } \\
\left({ }^{\circ}\right)\end{array}$ & $\begin{array}{c}\text { Average angle } \\
\left({ }^{\circ}\right)\end{array}$ \\
\hline $\mathrm{CCl}-\mathrm{V} 1$ & 38.03 & 6.32 & \multirow{3}{*}{6.71} & 40.3 & \multirow{3}{*}{38.7} \\
\hline $\mathrm{CC} 1-\mathrm{V} 2$ & 40.01 & 6.65 & & 34.7 & \\
\hline $\mathrm{CCl}-\mathrm{V} 3$ & 43.16 & 7.17 & & 41.2 & \\
\hline $\mathrm{CCO}-\mathrm{VI}$ & 38.77 & 5.98 & \multirow{3}{*}{5.95} & 38.5 & \multirow{3}{*}{38.4} \\
\hline $\mathrm{CCO}-\mathrm{V} 2$ & 38.56 & 5.94 & & 42.6 & \\
\hline $\mathrm{CCO}-\mathrm{V} 3$ & 38.41 & 5.92 & & 34.1 & \\
\hline CA1N - V1 & 36.75 & 5.29 & \multirow{3}{*}{5.40} & 34.4 & \multirow{3}{*}{34.6} \\
\hline $\mathrm{CA} 1 \mathrm{~N}-\mathrm{V} 2$ & 36.50 & 5.25 & & 32.9 & \\
\hline $\mathrm{CA} 1 \mathrm{~N}-\mathrm{V} 3$ & 39.31 & 5.66 & & 36.4 & \\
\hline CAON - V1 & 32.92 & 5.40 & \multirow{3}{*}{5.23} & 36.6 & \multirow{3}{*}{34.5} \\
\hline CAON - V2 & 30.90 & 5.07 & & 36.5 & \\
\hline CAON - V3 & 31.75 & 5.21 & & 30.3 & \\
\hline CAIR - V1 & 38.11 & 5.46 & \multirow{3}{*}{5.34} & 30.1 & \multirow{3}{*}{33.1} \\
\hline CA1R - V2 & 36.94 & 5.29 & & 34.3 & \\
\hline CA1R - V3 & 36.94 & 5.29 & & 31.9 & \\
\hline CAOR - VI & 33.48 & 4.97 & \multirow{3}{*}{5.37} & 38.4 & \multirow{3}{*}{33.6} \\
\hline CAOR - V2 & 39.92 & 5.92 & & 27.2 & \\
\hline CAOR - V3 & 35.24 & 5.23 & & 35.3 & \\
\hline
\end{tabular}

Due to variation of the compressive strength of the concrete mixes used in this study, beam shear strength analysis was carried out considering a normalized shear load, $\mathrm{V}_{\mathrm{n}}$, calculated as shown in Equation 1, by using the resistance correlation adopted by the $\mathrm{ACl}$ : $V_{n}=\frac{V_{u}}{\sqrt{f_{c}}}$

Where $V_{u}$ is the ultimate shear force $(k N)$ and $f_{c}$ is the compressive strength of concrete (MPa).

Table 3 presents the ultimate shear force, the normalized ultimate shear force, the average of ultimate shear force, and the inclination angle of the shear cracks for each beam tested.

The comparison between the average normalized ultimate shear forces and the shear crack inclination angles observed for conventional and self-consolidating concrete beams shows that higher shear strengths were achieved for beams with more inclined cracks. This would indicate the occurrence of a greater vertical force transfer through the crack. However, the results do not show a significant variation of the shear crack inclination when the volume or the size of the coarse aggregate changed.

Figure 7 presents the mean and the respective standard deviation values of the normalized ultimate shear force for the different beams. It can be observed that the conventional concrete beams achieved a mean normalized ultimate shear load higher than the self-consolidating concrete beams. Similar results were presented by Helincks et al. [14], where a reduction on the shear resistance of self-consolidating concrete was attributed to the smaller aggregate size and decreased volume of coarse aggregate in the mixes, thus resulting in lesser aggregate interlock. Moreover, it was observed that the amount of fines in the

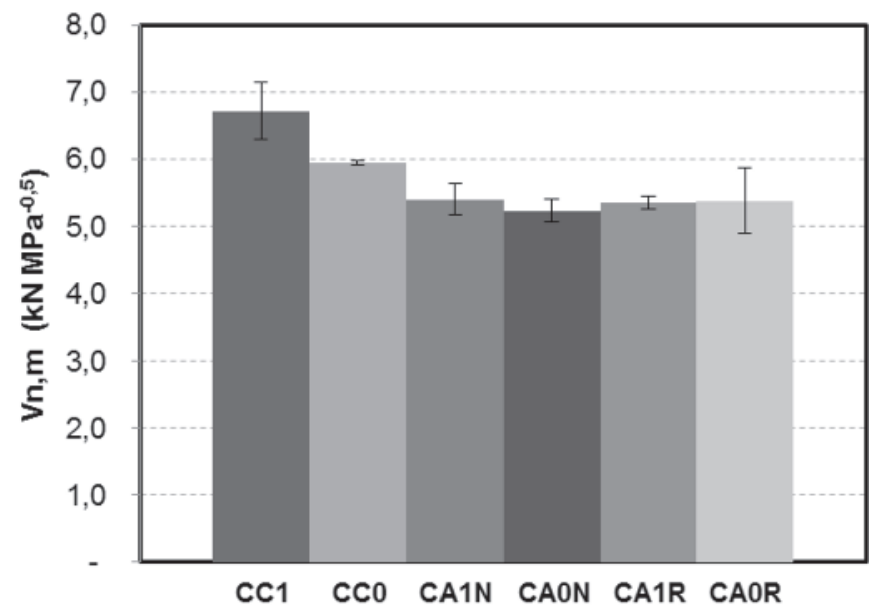

Figure 7

Mean and standard deviations values of the normalized ultimate shear load for all beams 
conventional mixes has influenced aggregate interlock, thus reducing the shear strength, since beam $\mathrm{CC} 1$ with a lower content of fine materials achieved higher strengths than beam CCO.

To evaluate the influence of some parameters of the concrete mixes on the shear strength of beams, such as the flowability, the maximum nominal diameter and the volume of coarse aggregate, the experimental results were analyzed grouped according to these parameters.

\section{a) Influence of flowability}

In order to achieve the required flowability for the self-consolidating concrete mixes, some amount of fine aggregates was replaced by limestone filler and superplasticizer was added to the mix. The effects of such changes on the shear strength can be evaluated when conventional concrete and self-consolidating mixes produced with the same diameter and volume of coarse aggregate are compared, i.e., $\mathrm{CC} 1 \times \mathrm{XA} 1 \mathrm{~N}$ and $\mathrm{CC} 0 \mathrm{xCA} 0 \mathrm{~N}$.

According to the results presented in Table 3, the average normalized ultimate shear force for conventional concrete was $24.3 \%$ higher than the one for self-consolidating concrete when larger coarse aggregates were used (6.71 kN.MPa- ${ }^{-0,5}$ for $\mathrm{CC} 1$ and $5.40 \mathrm{kN}^{\mathrm{MPPa}}{ }^{-0,5}$ for $\mathrm{CA} 1 \mathrm{~N})$. For mixes with smaller coarse aggregate, this difference was $13.8 \%$ (5.95 kN.MPa ${ }^{-0,5}$ for CC1 and $5.23 \mathrm{kN}^{\mathrm{MPa}} \mathrm{a}^{-0,5}$ for CA1N). Considering that the same flexural reinforcement was used in all beams, ensuring the same dowel action, it seems that besides the better compaction of the material, the use of a larger amount of fine material in self-consolidating concrete caused a reduction on aggregate interlock, and consequently a reduction on the shear strength, as also presented by Choulli et al. [15].

\section{b) Influence of the coarse aggregate volume}

The results obtained for self-consolidating concrete beams produced with the same coarse aggregate size, but with different volumes, CA1NxCA1R and CAONxCAOR, did not show significant variations in the ultimate shear resistance of the beams, with differences lower than $3 \%$. Among conventional and self-consolidating concrete, it was observed that the reduction of the coarse aggregate volume combined with fine aggregate replacement by fine materials resulted in a greater reduction on the shear strength for concrete beams with largest aggregate size. While among beams CCOxCAOR no significant variation on resistance was observed, among beams CC1xCA1R there was an observed reduction of $20.4 \%$ on the average ultimate normalized resistance. Similar results were presented by Hassan et al. [14] and Helincks et al. [16], where the reduction

\section{Table 4}

Ultimate shear load form experiments, code based prediction and these values ratio

\begin{tabular}{|c|c|c|c|c|c|c|}
\hline \multirow[b]{2}{*}{ Concrete } & \multicolumn{2}{|c|}{ Experimental } & \multicolumn{2}{|c|}{ Code based prediction } & \multicolumn{2}{|c|}{ Comparison (Ratio) } \\
\hline & $\begin{array}{c}V_{u} \\
(k N)\end{array}$ & $\begin{array}{l}V_{u, m} \\
(k N)\end{array}$ & $\begin{array}{l}\mathrm{V}_{\mathrm{u}, \mathrm{ACI}} \\
(\mathrm{KN})\end{array}$ & $\begin{array}{l}V_{\mathrm{u}, \mathrm{EC}} \\
(\mathrm{kNN})\end{array}$ & $\mathrm{V}_{\mathrm{u}, \mathrm{ACl}} / \mathrm{V}_{\mathrm{u}, \mathrm{m}}$ & $\mathrm{v}_{\mathrm{u}, \mathrm{EC}} / \mathrm{v}_{\mathrm{u}, \mathrm{m}}$ \\
\hline $\mathrm{CC} 1-\mathrm{V} 1$ & 38.03 & \multirow{3}{*}{40.4} & \multirow{3}{*}{22.12} & \multirow{3}{*}{31.31} & \multirow{3}{*}{0.55} & \multirow{3}{*}{0.78} \\
\hline $\mathrm{CC} 1-\mathrm{V} 2$ & 40.01 & & & & & \\
\hline $\mathrm{CCl}-\mathrm{V} 3$ & 43.16 & & & & & \\
\hline $\mathrm{CCO}-\mathrm{V} 1$ & 38.77 & \multirow{3}{*}{38.6} & \multirow{3}{*}{23.60} & \multirow{3}{*}{32.92} & \multirow{3}{*}{0.61} & \multirow{3}{*}{0.85} \\
\hline $\mathrm{CCO}-\mathrm{V} 2$ & 38.56 & & & & & \\
\hline $\mathrm{CCO}-\mathrm{V} 3$ & 38.41 & & & & & \\
\hline CA1N - V1 & 36.75 & \multirow{3}{*}{37.5} & \multirow{3}{*}{25.07} & \multirow{3}{*}{34.46} & \multirow{3}{*}{0.67} & \multirow{3}{*}{0.92} \\
\hline $\mathrm{CA} 1 \mathrm{~N}-\mathrm{V} 2$ & 36.50 & & & & & \\
\hline CA1N - V3 & 39.31 & & & & & \\
\hline CAON - V1 & 32.92 & \multirow{3}{*}{31.9} & \multirow{3}{*}{22.37} & \multirow{3}{*}{31.58} & \multirow{3}{*}{0.70} & \multirow{3}{*}{0.99} \\
\hline CAON - V2 & 30.90 & & & & & \\
\hline CAON - V3 & 31.75 & & & & & \\
\hline CAIR - V1 & 38.11 & \multirow{3}{*}{37.3} & \multirow{3}{*}{25.18} & \multirow{3}{*}{34.58} & \multirow{3}{*}{0.67} & \multirow{3}{*}{0.93} \\
\hline $\mathrm{CA} 1 \mathrm{R}-\mathrm{V} 2$ & 36.94 & & & & & \\
\hline $\mathrm{CA} 1 \mathrm{R}-\mathrm{V} 3$ & 36.94 & & & & & \\
\hline CAOR - V1 & 33.48 & \multirow{3}{*}{36.2} & \multirow{3}{*}{24.39} & \multirow{3}{*}{33.75} & \multirow{3}{*}{0.67} & \multirow{3}{*}{0.93} \\
\hline CAOR - V2 & 39.92 & & & & & \\
\hline CAOR - V3 & 35.24 & & & & & \\
\hline
\end{tabular}


on shear strength were attributed to lower aggregate interlock due to the reduced volume of coarse aggregate.

\section{c) Influence of the coarse aggregate nominal size}

Since the concrete beams $\mathrm{CC} 1 \times \mathrm{CC} 0, \mathrm{CA} 1 \mathrm{NxCA0N}$ and CA1RxCA0R differentiate only by the coarse aggregate size, the influence of this parameter on their shear strength can be evaluated by comparing the observed values among these beams.

The reduction of the coarse aggregate size showed higher influence on conventional concrete beams, with ultimate shear force of CC1 $12.8 \%$ higher than the one of CCO.

For self-consolidating concrete, there was not an observed significant reduction in the shear strength for beams with different coarse aggregate sizes. The variation on ultimate strength for $\mathrm{CA} 1 \mathrm{~N}$ was $3.3 \%$ higher than for $\mathrm{CAON}$, while for CA1R this resistance was practically the same as CAOR.

\subsection{Comparison of test results with codes predictions}

The ultimate shear resistances obtained from the conventional and self-consolidating concrete beams tests were compared to the ones estimated by ACl-318 [9] and EC-2 [10] equations (2) and (3), respectively, for shear resistance $\left(V_{R}\right)$ of beams without shear reinforcement. A safety factor equal to 1.0 was applied.

$V_{R}=\left(\sqrt{f_{c}}+120 \cdot \rho_{l} \cdot \frac{V_{u} \cdot d}{M_{u}}\right) \cdot \frac{b_{w} \cdot d}{7} \leq 0,3 \cdot \sqrt{f_{c}} \cdot b_{w} \cdot d$

$V_{R}=0,18 \cdot\left(1+\sqrt{\frac{200}{d}}\right) \cdot\left(100 \cdot \rho_{l} \cdot f_{c}\right)^{1 / 3} \cdot b_{w} \cdot d$

Where $f_{c}$ is the concrete compressive strength (MPa), $\rho$ is the flexural reinforcement ratio, $V_{u}$ is the ultimate shear force $(k N), M_{u}$ is the ultimate bending moment $(\mathrm{kN} . \mathrm{m}), \mathrm{b}_{\mathrm{w}}$ is the beam width $(\mathrm{m})$ and $d$ is the effective depth of the beam cross section ( $m$ ).

Table 4 presents the ultimate shear resistance obtained experimentally and the ones given by the code based predictions. For both codes, the self-consolidating concrete shear strength estimative was less conservative than the one for conventionally vibrated concrete shear strength.

$\mathrm{ACl} 318$ equation underestimated the ultimate strength of concrete beams without shear reinforcement, with the ratio between predicted to experimental values ranging from 0.55 to 0.70 . An average ratio value of 0.65 was obtained from all beam results. ACI 318 equation was found to be less conservative for self-consolidating concrete beams.

The ratio between predicted values given by EC-2 to experimental values were between 0.78 and 0.99 . Similar to $A C I, E C-2$ values were less conservative for self-consolidating concrete. In fact, the values estimated for the self-consolidating concrete beams were close to the experimental values, especially for CAON, indicating a reduction in the safety factor for beams cast with this material as compared to conventionally vibrated concrete beams.

Even though the $\mathrm{ACl} 318$ equation considers a greater contribution of concrete compressive strength on the shear resistant of beams

\section{Table 5}

Ratio bewteen ultimate shear loads given by codes to the ones obtained experimentally for conventional and self-consolidating concrete beams

\begin{tabular}{|c|c|c|}
\hline Concrete & $\mathrm{V}_{\mathrm{u}, \mathrm{ACl}} / \mathrm{V}_{\mathrm{u}, \mathrm{m}}$ & $\mathrm{V}_{\mathrm{u}, \mathrm{EC}} / \mathrm{V}_{\mathrm{u}, \mathrm{m}}$ \\
\hline Conventional (1) & 0.58 & 0.81 \\
\hline $\begin{array}{c}\text { Self- } \\
\text { consolidating (2) }\end{array}$ & 0.68 & 0.94 \\
\hline$(1) /(2)$ & 0.85 & 0.86 \\
\hline
\end{tabular}

as compared to the EC-2, the results show that shear resistances estimated by this code were more conservative, regardless of the concrete type.

The ratio between the average ultimate shear resistance estimated by the codes to the ones obtained experimentally for conventional and self-consolidating concrete beams (Table 5) were similar, being equal to 0.85 and 0.86 for $\mathrm{ACl} 318$ and $\mathrm{EC}-2$, respectively.

\section{Conclusions}

Despite the small number of beams tested, it was possible to evaluate the influence of volume fraction and size of coarse aggregate on shear resistance of beams produced with these materials, even though a larger number of samples would be necessary for a complete evaluation of the influence of the parameters that differentiate conventionally vibrated to self-consolidating concretes behavior.

Regardless of the type of concrete, the beams showed similar behavior during the tests. Initially, flexural cracks in the mid-span of the beam appeared together with few cracks with small slope in the shear regions. In the final stages of loading, a sudden formation of inclined crack occurred which was followed by failure.

The inclination of the shear cracks ranged between $27.2^{\circ}$ to 42.6 $\circ$. Conventional concrete beams showed a greater average value when compared to self-consolidating concrete beam values. The more inclined shear cracks resulted in higher shear strength due to greater transfer of forces through the crack.

Beams cast with conventional concrete mixes showed higher shear strengths than the ones obtained for self-consolidating concrete mixes with same size and volume fraction of coarse aggregate. This reduction on resistance of self-consolidating concrete beams can be attributed to the higher content of fine materials, thus reducing the aggregate interlock.

Among the self-consolidating concrete mixes, it was observed that the reduction of coarse aggregate volume did not influence the ultimate resistance, probably due to the similar amount of fines in their mix proportions. A higher effect of reducing the volume of coarse aggregate was observed between CC1 and CA1R, also due to the replacement of the fine aggregate by filler.

The size reduction of coarse aggregate in the mixture resulted in a reduction of the ultimate normalized shear force for conventional concrete beams. The same effect, however, was not observed for self-consolidating concretes beams.

$\mathrm{ACl} 318$ and EC-2 code equations yielded less conservative values for shear predictions of self-consolidating concrete beams than for 
conventionally vibrated concrete beams. $\mathrm{ACl} 318$ equation underestimated the ultimate strength of concrete beams without shear reinforcement, with a ratio of predicted to experimental values ranging from 0.55 and 0.70 . EC-2 equation provided less conservative estimates than the $\mathrm{ACl} 318$, with the ratio of predicted to experimental values between 0.78 and 0.85 for conventional concrete and between 0.92 and 0.99 for self-consolidating concrete, indicating a reduction on safety of the structures when used this material.

\section{Acknowledgements}

The authors gratefully acknowledge the Coordination for the Improvement of Higher Education Personnel (CAPES) and the Graduate Program in Civil Engineering of the Federal University of Santa Catarina for support, as well as Professor Wellington Longuini Repette and doctoral student Ronaldo Pilar by major collaborations in the development of the concrete mixes.

\section{References}

[1] OKAMURA, H., OUCHI, M., Self-consolidating Concrete. Journal of Advanced Concrete Technology, Vol. 1, No. 1, 5-15, 2003

[2] REPETTE, W. L. Concreto autoadensável. In: Geraldo Cechella Isaia. (Org). Concreto: Ciência e Tecnologia. 1ed. São Paulo: IBRACON, 2011, V.2, P. 1769-1806.

[3] EFNARC. Specification and Guidelines for Self-consolidating Concrete. European Federation of Specialist Construction Chemicals and Concrete Systems, 2005.

[4] PARRA, C., VALCUENDE, M., GÓMEZ, F.. Splitting tensile strength and modulus of elasticity of self-consolidating concrete. Construction and Building Materials, v. 25, p. 193-198, 2011.

[5] SHERWOOD, E. G., BENTZ, E. C., COLINS, M. P.. Evaluation of shear design methods for large, lightly-reinforced concrete beams. Advances in Engineering Structures, Mechanics \& Construction, p. 153-164, Springer: Netherlands, 2006.

[6] YANG, K. H., SIM, J. I., CHOI, B. J., LEE, E. T.. Effect of Aggregate Size on Shear Behavior of Lightweight Concrete Continuous Slender Beams. ACI Materials Journal, V. 108, $N^{\circ}$ 5, Sep.-Oct. 2011, p. 501-509.

[7] HASSAN, A. A. A., HOSSAIN, K. M. A., LACHEMI, M.. Behavior of full-scale self-consolidating concrete beams in shear. Cement \& Concrete Composites, 30 (2008) 588-596.

[8] DESNERCK, P., DE SCHUTTER, G., TAERWE, L.. Shear friction of reinforced self-consolidating concrete members. ACl Special publication 261-9. American Concrete Institute, Farmington Hills, Michigan. p. 133-141, 2009.

[9] $\mathrm{ACl}$ Committee 318, Building code requirements for structural concrete and commentary. American Concrete Institute, Farmington Hills, Michigan, 2011.

[10] Eurocode 2. Design of concrete structures - Part 1-1: General rules and rules for buildings. 2004.

[11] ASSOCIAÇÃO BRASILEIRA DE NORMAS TÉCNICAS. NBR NM 67: Concreto - Determinação da consistência pelo abatimento do tronco de cone. Rio de Janeiro, 1998.

[12] ASSOCIAÇÃO BRASILEIRA DE NORMAS TÉCNICAS. NBR 15823: Concreto autoadensável. Rio de Janeiro, 2010.
[13] ASSOCIAÇÃO BRASILEIRA DE NORMAS TÉCNICAS. NBR 5739: Concreto - Ensaio de compressão de corposde-prova cilíndricos. Rio de Janeiro, 2007.

[14] HELINCKS, P., BOEL, V., DE CORTE, W., DE SCHUTTER, G., DESNERCK, P.. Structural behaviour of power-type selfconsolidating concrete: Bond performance and shear capacity. Engineering Structures, V. 48, p. 121-132, 2013.

[15] CHOULLI, Y., MARÍ, A. R., CLADERA, A.. Shear behaviour of full-scale prestressed-beams made with self compacting concrete. Materials and Structures, $n^{\circ} 41$, p. 131-141, 2008.

[16] HASSAN, A. A. A., HOSSAIN, K. M. A., LACHEMI, M.. Strength, cracking and deflection performance of large-scale self-consolidating concrete beams subjected to shear failure. Engineering Structures, 32 (2010) 1262-1271. 